\begin{tabular}{|l|l|l|}
\hline \multicolumn{2}{|c|}{ PublisherInfo } \\
\hline \hline PublisherName & $:$ & BioMed Central \\
\hline \hline PublisherLocation & $:$ & London \\
\hline \hline PublisherImprintName & $:$ & BioMed Central \\
\hline \hline
\end{tabular}

\title{
A twist on ribosomal protein function
}

\begin{tabular}{||l|l|l||}
\hline \multicolumn{2}{|c||}{ ArticleInfo } \\
\hline \hline ArticleID & $:$ & 4860 \\
\hline \hline ArticleDOI & $:$ & $10.1186 /$ gb-spotlight-20031022-01 \\
\hline \hline ArticleCitationID & $:$ & spotlight-20031022-01 \\
\hline \hline ArticleSequenceNumber & $:$ & 212 \\
\hline \hline ArticleCategory & $:$ & Research news \\
\hline ArticleFirstPage & $:$ & 1 \\
\hline \hline ArticleLastPage & $:$ & 3 \\
\hline \hline & & RegistrationDate : 2003-10-22 \\
ArticleHistory & $:$ & OnlineDate $\quad$ 2003-10-22 \\
\hline \hline ArticleCopyright & $:$ & BioMed Central Ltd2003 \\
\hline \hline ArticleGrants & $:$ & \\
\hline \hline ArticleContext & $:$ & 130594411 \\
\hline \hline
\end{tabular}




\section{David Secko}

Email: dmsecko@interchange.ubc.ca

Control of many mRNA transcripts occurs at the translational level, a mechanism that commonly functions through the binding of proteins to the untranslated region of a target mRNA. Ceruloplasmin $(\mathrm{Cp})$ - a protein locally secreted at inflammatory sites by cytokine-stimulated macrophages - is subject to such translational silencing. Interferon (IFN)- $\gamma$ induces Cp expression, which is then subjected to translational silencing approximately 16 hours after the IFN- $\gamma$ treatment. This process is mediated by a 29 nucleotide area of the Cp mRNA and thought to involve the binding of cytosolic proteins, but the identity of the proteins involved has been unclear. In the October 17 Cell, Barsanjit Mazumder and colleagues from the Lerner Research Institute have identified the Cp mRNA binding protein to be the ribosomal protein L13a, revealing it to have a bi-functional role in the cell (Cell, 115:187-198, October 17, 2003).

Mazumder et al. used a three-hybrid screen (involving an mRNA and two proteins) to identify the human ribosomal protein L13a - an integral component of the large ribosomal subunit with unknown function - as an inhibitor of the translation of Cp mRNA. L13a was observed to bind to Cp mRNA, but only after 24 hours of IFN- $\gamma$ treatment, suggesting that an unidentified mechanism delayed its interaction. Insect cells expressing recombinant L13a protein were tested and observed to have Cp translational silencing activity, while Escherichia coli expressing L13a lacked such activity. This, together with the delayed interaction of L13a, suggests that the posttranslational modification of L13a occurs upon IFN- $\gamma$ treatment, thereby controlling its translational silencing activity.

A modification could explain how an ever-present ribosomal protein could selectively inhibit mRNA only under certain conditions. Mazumder et al. then showed - through the use of phosphatases and metabolic ${ }^{32} \mathrm{P}$ labeling - that L13a was phosphorylated in a delayed fashion by IFN- $\gamma$ treatment. In addition, phosphorylation was shown to be necessary for L13a silencing activity. Localization studies showed that phosphorylated L13a was no longer attached to ribosomes, revealing that IFN- $\gamma$ treatment caused L13a to be released, allowing it to function in Cp translational silencing.

"Our results indicate that the ribosome, in addition to functioning as a protein synthesis machine, also acts as a depot for releasable regulators of protein translation," conclude the authors.

In an accompanying preview article, Robert A. Zimmermann from the University of Massachusetts comments that "perhaps L13a establishes a new paradigm, a translational regulatory 'factor in waiting'; for which... the ribosome merely serves as a convenient depot." 


\section{References}

1. Translational control by the 3'-UTR: the ends specify the means

2. Transcript-selective translational silencing by gamma interferon is directed by a novel structural element in the ceruloplasmin mRNA 3' untranslated region

3. Cell, [http://www.cell.com]

4. Lerner Research Institute, [http://www.lerner.ccf.org/]

5. The structural basis of large ribosomal subunit function

6. University of Massachusetts, [http://www.umass.edu/]

This PDF file was created after publication. 